\title{
STRATEGI PEMASARAN PENGELOLAAN LIMBAH MEDIS PADA PT. PRASADHA PAMUNAH LIMBAH INDUSTRI (PPLI)
}

\author{
MARKETING STRATEGY ANALYSIS OF MEDICAL WASTE \\ PT. PRASADHA PAMUNAH LIMBAH INDUSTRY ( PPLI)
}

\author{
Imam Zulkarnain ${ }^{* 1}$, Harianto**), dan Kirbrandoko $\left.{ }^{* * *}\right)$ \\ *) Sekolah Bisnis, IPB University \\ Jl. Raya Padjajaran, Bogor 16151, Indonesia \\ ${ }^{* *}$ Departemen Agribisnis, Fakultas Ekonomi dan Manajemen, IPB University \\ Jl. Agatis Kampus IPB Dramaga, Bogor 16680, Indonesia \\ $\left.{ }^{* * *}\right)$ Universitas Ibn Khaldun Bogor \\ Jl. Sholeh Iskandar, Tanah Sereal, Bogor 16162, Indonesia
}

\begin{abstract}
According to the Indonesia Health Profile Information (http://kemenkes.go.id/) in 2018 reported estimates of the amount of medical waste that every day 2,820 hospitals in Indonesia are 230,840 $\mathrm{kg}$ per day. To date the best technology for treating and disposal medical waste is incinerators. In middle of 2019 PPLI decided to build an incinerator so that this was a new line of business for PPLI (Prasadha Pamunah Limbah Industri), this is very interesting when at one side PPLI is the big player in hazardous waste management but at another side PPLI is new comer for medical waste management, with the aim of analyzing the market at medical waste management service, identify of actors, factors and objectives that influence the medical waste management business. Through the swot analysis method it was found that PPLI was in quadrant 1, which means that PPLI has great strength and support from external side to succeed in medical waste management service business, which means PPLI facilities and services are complete so that mean PPLI can be the one company for Total Hazardous Waste Management in Indonesia.
\end{abstract}

Keywords: hospital, medical waste, total hazardous waste management, PPLI, SWOT

\begin{abstract}
Abstrak: Menurut Informasi Profil Kesehatan Indonesia (http://kemenkes.go.id/) pada tahun 2018 melaporkan perkiraan jumlah limbah medis yang setiap hari 2.820 rumah sakit di Indonesia adalah $230.840 \mathrm{~kg}$ per hari. Sampai saat ini teknologi terbaik untuk mengolah dan memusnahkan limbah medis adalah incinerator. Pada pertengahan 2019 PPLI (Prasadha Pamunah Limbah Industri) memutuskan untuk membangun incinerator, yang merupakan lini bisnis baru untuk PPLI, ini sangat menarik ketika di satu sisi PPLI adalah pemain besar dalam pengelolaan limbah bahan berbahaya dan beracun tetapi di sisi lain PPLI adalah pendatang baru untuk pengelolaan limbah medis, dengan tujuan menganalis pasar pada jasa pengelolan limbah medis, identifikasi aktor, faktor penentu dan tujuan yang berpengaruh dalam bisnis pengelolaan limbah medis. Dengan menggunakan metode analisis SWOT yang ditemukan bahwa PPLI berada di kuadran 1 yang berarti PPLI memiliki kekuatan besar dan dukungan dari lingkungan eksternal untuk berhasil dalam bisnis jasa pengelolaan limbah medis. Artinya, telah lengkaplah fasilitas dan pelayanan PPLI sehingga PPLI dapat melakukan total pengelolaan limbah bahan berbahaya dan beracun di Indonesia.
\end{abstract}

Kata kunci: rumah sakit, limbah medis, total pengelolaan limbah berbahaya, PPLI, SWOT

${ }^{1}$ Corresponding author:

Email: imam.dowa@gmail.com 


\section{PENDAHULUAN}

Rumah sakit dan fasilitas pelayanan kesehatan senantiasa dihadapkan dalam permasalahan limbah medis yang pastinya akan dihasilkan dari setiap kegiatan pelayanan kesehatan yang diberikan. Limbah medis yang dihasilkan dari pelayanan kesehatan hanya $10 \%$ sampai $25 \%$ saja dimana selebihnya adalah limbah domestic (Pruss et al. 2005). Menurut WHO (2014) rata rata limbah rumah sakit di negara berkembang berkisar 1 hingga $3 \mathrm{~kg} /$ tempat tidur setiap harinya, sedangkan dinegara maju mencapai 5 hingga $8 \mathrm{~kg}$ per tempat tidur setiap harinya. Berdasarkan Keputusan Menteri Kesehatan Nomor 1204 Tahun 2004 tentang persyaratan Kesehatan Lingkungan Rumah Sakit, dijelaskan bahwa limbah medis padat adalah limbah padat yang terdiri dari limbah infeksius, limbah patologi, limbah benda tajam, limbah sitotoksis, limbah kimiawi, limbah radioaktif, limbah kontainer bertekanan dan limbah dengan kandungan logam berat (KEPEMENKES RI. No1204/Menkes/SK/x/2004).

Limbah medis yang dihasilkan dari pelayanan kesehatan hanya $10 \%$ sampai $25 \%$ saja dimana selebihnya adalah limbah domestic (Pruss et al. 2005). Bila dilihat persentasinya, jumlah limbah medis yang dihasilkan memang sedikit namun resiko terhadap kesehatan sangat besar apalagi bila tidak dilakukan pengelolaan dengan benar, selain resiko kecelakaan kerja dan penularan penyakit baik bagi pelaku pelayanan kesehatan mulai dari dokter, perawat, teknisi dan semua yang berkaitan dengan pengelolaan rumah sakit maupun perawatan pasien dan pengunjung rumah sakit tersebut (Munif, 2010). Menurut Informasi Profile Kesehatan Indonesia (http://kemenkes.go.id/) tahun 2015 ada 2,490 rumah sakit dengan estimasi limbah medis sebanyak 206,670 kg per hari. Pada tahun 2016 ada 2,601 Rumah Sakit dengan limbah medis sebanyak 215,883 kg per hari, tahun 2017 ada 2,773 Rumah Sakit dengan limbah medis sebanyak 230,159 kg per hari tahun 2018 melaporkan estimasi jumlah limbah medis yang dihasilkan setiap harinya seluruh rumah sakit yang berjumlah 2,820 di Indonesia adalah $233.210 \mathrm{~kg}$ per hari, dan jika saja limbah medis tidak dikelola dengan baik, maka kondisi tersebut akan memperbesar kemungkinan potensi limbah rumah sakit dalam mencemari lingkungan serta menularkan penyakit dan juga dapat mengakibatkan kecelakaan kerja (Pertiwi, 2017). Untuk memudahkan pengenalan jenis limbah adalah dengan cara menggunakan kantong berwarna yaitu kantong warna hitam untuk limbah domestik, kantong kuning untuk semua jenis limbah yang akan dibakar (limbah infeksius), kuning dengan strip hitam untuk jenis limbah yang sebaiknya dibakar, biru muda atau transparan dengan strip biru tua untuk limbah autoclaving (pengolahan sejenis) sebelum pembuangan akhir (Asmadi, 2013). Insinerator yang dirancang baik, mampu menghancurkan kandungan organik yang berbahaya dari limbah B3. Sebaliknya, perancangan dan pengoperasian insinerator yang tidak sempurna akan membahayakan kesehatan manusia dan lingkungan, melalui emisi gas beracun dan pencemar lain ke atmosfer (Nurhayati, 2011). Saat ini hanya ada 85 rumah sakit diseluruh Indonesia yang memiliki insenerator dan hanya 12 perusahaan swasta yang bergerak pada jasa pengelolaan limbah yang memiliki Insenerator. Dari ke 12 perusahaan yang memiliki izin fasilitas insinerator yang dikeluarkan oleh kementrian lingkungan hidup dan kehutanan untuk mengelola limbah medis tidak terdapat nama PT. PPLI (Prasadha Pamunah Limbah Industri) yang merupakan pionir pengelolaan limbah B3 (Bahan Berbahaya dan Beracun). Hal ini sangat menarik dimana PT. PPLI yang merupakan tolak ukur pengelolaan limbah B3 di Indonesia belum mempunyai fasilitas incinerator untuk menjawab tantangan permasalahan dalam pengelolaan limbah medis yang ada di Indonesia, walaupun hasil buangan pembakaran yang merupakan abu incinerator harus dikelola dan dimusnahkan. Seperti halnya yang dilakukan oleh RSUD Dr. Soetomo yang menyerahkan abu sisa pembakaran incinerator ke pihak ke-3 yang memiliki legalitas untuk pengelolaan limbah ash insinerator. Kontrak kerjasama didalam penanganan limbah antara RSUD Dr. Soetomo dengan PT PPLI sebagai pihak ke-3 pengelola limbah telah dibuat berdasarkan kontrak Kerjasama No.116/12681.1/301/2016. Pengiriman residu ke pihak ke-3 menggunakan kendaraan PT. PPLI (Alvionita, 2018). Hingga akhirnya pada tahun 2019, PT. PPLI memutuskan untuk membangun fasilitas baru, yaitu Insinerator yang merupakan lini bisnis baru PPLI untuk ditawarkan kepada penghasil limbah medis.

Sehingga dibutuhkan sebuah analisis yang menyeluruh agar PPLI dapat berhasil di bisnis pengelolaan limbah medis seperti hal nya limbah B3 lainnya, melalui pencarian faktor dan aktor penentu bisnis, hingga menemukan posisi PPLI dalam kuadran SWOT akan sangat menentukan strategi untuk keberhasilan PPLI dalam bisnis pengelolaan limbah medis di Indonesia, Berdasarkan hasil wawancara mendalam kepada aktor penentu bisnis pengelolaan limbah medis di 
Indonesia didapatkan informasi fasilitas dan kapasitas incinerator pada beberapa perusahaan swasta dengan kapasitas cukup baik yang memberikan penawaran jasa pengelolaan limbah medis antara lain PT. JM dengan kapasitas 2 insinerator 40 ton/hari, PT. WI 3 insinerator 30 ton/hari PT.TJ memiliki 1 insinerator 7 ton/hari, PT.PRI memiliki 2 insinerator total 20 ton/hari, PT.PLK, memiliki 1 insinerator 12 ton/ hari, PT.AEI, memiliki 2 insinerator total 12 ton/hari, PT.AM 1 insinerator 10 ton/hari, PT.MH 1 insineratro 12 ton/hari. Melihat kondisi dan situasi ini, dimana perusahaan swasta penyedia jasa pengelolaan limbah medis yang telah telebih dahulu memiliki pengalaman dan fasilitas incinerator maka dari kondisi dan situasi tersebut diperlukanlah masukan kepada pengurus PPLI yang akan merumuskan strategi pemasaran untuk dapat sukses dan menang dalam lini bisnis baru bagi perusahaannya ini.

Belum ditemukan penelitian - penelitian sebelumnya yang khusus untuk bisnis jasa pengelolaan limbah medis dari sisi perusahaan penyedia jasa pengelolaan limbah medis di Indonesia. Kemungkinan besar ini adalah penelitian pertama yang khusus untuk bisnis jasa pengelolaan limbah medis langsung dari penyedia jasa atau perusahaan pengolah limbah medis. Tujuan penelitian ini adalah menganalisis pasar di industri pengelolaan limbah medis, mengidentifikasi faktor dan aktor yang berperan dan berpengaruh dalam strategi pemasaran pengelolaan limbah medis serta menentukan strategi pemasaran yang sesuai untuk dilakukan PPLI secara efektif dan efisien untuk memenangkan persaingan industri pengelolaan limbah medis di Indonesia.

\section{METODE}

Penelitian ini berlokasi di PT PPLI yang berlokasi Jalan Narogong, Desa Nambo, Kecamatan Cileungsi, Kabupaten Bogor, serta di Kementerian Lingkungan Hidup dan Kehutanan (KLHK) dan Kementerian Kesehatan (Kemenkes), serta di 15 rumah sakit yang tersebar di Jabodetabek. Penelitian dilakukan sejak bulan Januari 2020 hingga bulan Februari 2020.

Penelitian ini menggunakan metode kuantitatif dan kualitatif, dimana data kuantitatif diambil dari sebaran kuesioner survey kepada 15 Rumah Sakit sebagai responden, dan kualitatif dilakukan dengan wawancara mendalam (Focus Group Discussion) kepada PPLI, KLHK dan KEMENKES. Dengan dukungan data dari
PPLI, KLHK, dan KEMENKES seperti data penyedia jasa dan harga pengelolaan limbah medis, berupa pengelolaan limbah B3 terutama limbah medis, dan fasilitas serta kapasitas PPLI untuk mengelola limbah medis. Sedangkan data skunder berupa data tambahan dari KLHK, dan KEMENKES seperti informasi seputar rumah sakit dan timbulan limbah medis diseluruh Indonesia.

Digunakan Teknik Analisis SWOT adalah untuk dapat menemukan posisi PT. PPLI dalam kuadran SWOT sehingga analisis dan rekomendasi yang diberikan akan berguna untuk memperoleh formulasi strategi yang tepat. Analisis SWOT memiliki beberapa kelebihan, diantaranya mampu mendeteksikan setiap kelemahan dan kelebihan sebuah institusi sehingga bermanfaat dalam meminimalisasi dampak atau konsekuensi yang akan terjadi dimasa akan datang (Coman, 2009).

Analisis SWOT dengan kajian diagnosis yang akan dilakukan dimulai dari menilai kondisi, permasalahan, serta pengaruh pasar pengolahan limbah medis yang akan dihadapi oleh PT. PPLI, Melakukan wawancara mendalam (indepth interview) kepada PPLI bertujuan untuk mengetahui faktor strength dan weakness PPLI dalam pengelolaan limbah medis, wawancara kepada KLHK untuk mendapatkan informasi akurat mengenai penegakan hukum dan pengawasan terhadap pengelolaan limbah medis dan wawancara kepada KEMENKES untuk mendapatkan informasi akurat mengenai kebijakan dan kebutuhan secara umum rumah sakit terhadap pihak ketiga dalam pengelolaan limbah medis. Hasil dari tahapan wawancara ini adalah didapatkannya KSF (Key Success Factor) yang memerngaruhi bisnis pengelolaan limbah medis di Indonesia.

Survey dilakukan terhadap 15 rumah sakit untuk dapat mengetahui posisi kuadran SWOT PPLI yang kemudian membuat matriks TOWS dengan akurat. Selanjutnya, matriks TOWS disusun untuk mengembangkan empat tipe pilihan strategi, yaitu SO, WO, ST, dan WT. Masing-masing tipe akan membentuk strategi antara lain: Strategi Strengths Opportunity (SO) dibuat dengan menggunakan kekuatan PPLI untuk memaksimalkan keuntungan dari peluang yang ada; Strategi Weaknesses Opportunity (WO) dibuat untuk memperbaiki dan menutup kelemahan PPLI dan menggunakan kesempatan eksternal dalam jangkauan yang bisa dimaksimalkan PPLI; Strategi Strengths Threats (ST) dibuat untuk mengantisipasi 
ancaman dengan menggunakan kekuatan yang dimiliki PPLI; Strategi Weakness Threats (WT) dibuat untuk mengantisipasi hal yang paling tidak diinginkan untuk dialami PPLI. Dengan rincian tersebut maka manajemen PPLI dapat mengetahui dengan pasti posisi perusahaannya dalam kuadran SWOT. Sehingga dapat mengukur dengan pasti bagaimana kemampuan dalam merencanakan strategi pemasaran, pertumbuhan dan juga dapat mengantisipasi masa depan dengan bantuan matrik TOWS yang dibuat. Pada akhirnya akan diberikan beberapa rekomendasi yang terkait dengan strategi pemasaran untuk menguasai pasar pada bisnis pengelolaan limbah medis ini. Selanjutnya, kerangka pemikiran dibuat untuk mempermudahkan memahami konseptual teori berhubungan dengan segala macam faktor yang telah diidentifikasi sebagai masalah penting, maka kerangka pemikiran penelitian pada Gambar 1.

\section{HASIL}

\section{Gambaran Umum PT. PPLI}

PT. Prasadha Pamunah Limbah Industri (PPLI) adalah perusahaan yang bergerak pada jasa pengolahan limbah bahan berbahaya dan beracun (Limbah B3) sejak tahun 1994 dan merupakan perusahaan pertama di kawasan ASEAN, berlokasi di Jalan Raya Narogong, Desa Nambo, Kecamatan Klapanunggal Cileungsi Kabupaten Bogor. Perusahaan yang diprakarsai Presiden Republik Indonesia kedua ini dirancang dan dibangun untuk mengatasi dampak lingkungan dan menurunnya kualitas lingkungan hidup akibat pesatnya industrialisasi yang akan terus tumbuh di Negara Kesatuan Republik Indonesia. Saat ini melalui DOWA Eco-System yang merupakan group dari DOWA Holding adalah kooperasi Jepang dan memiliki pengalaman lebih dari 100 tahun dalam bidang usaha pertambangan dan pengelolaan limbah B3, sepenuhnya memiliki saham $95 \%$ dan $5 \%$ dimiliki oleh Kementrian Badan Usaha Milik Negara. Pada perjalan bisnis yang dimulai dari 1994 hingga kini, PPLI masih tetap menjadi barometer pengolahan limbah di Indonesia, ini dikarenakan fasilitas yang dimiliki PPLI sepenuhnya digunakan untuk mengolah dan memusnahkan hampir seluruh limbah B3 kecuali infeksius dan radioaktif, Para ahli yang dimiliki
PPLI mampu memberikan tingkat pelayanan dan kenyamanan lingkungan yang konsisten dengan standar internasional dan memastikan perusahaan atau organisasi konsumen mematuhi peraturan internasional seperti tentang system manajemen ISO 9001, ISO 14001, OHSAS 18001, dan ISO/IEC 17025 dari KAN tentang Pengelolaan Laboratorium serta meminimasi kewajiban lingkungan di masa depan atas hal ini pula lah PPLI tetap menjadi leader market dalam bisnis jasa pengolahan dan pemusnahan limbah B3 di Indonesia Limbah yang diolah dan dimusnahkan terdiri dari 2 jenis limbah B3 yaitu padat (solid) dan cair (liquid) serta limbah yang dapat di daur ulang seperti kertas, besi dan plastic. Dengan rincian fasilitas pengolahan dan pemusnahan limbah B3 (PT. PPLI, 2018) sebagai berikut: Secure Landfill (Landfill atau lahan penimbunan adalah tempat penimbunan akhir limbah B3 yang direkayasa dengan standar yang paling tinggi); Solid Waste Treatment (Pengolahan Limbah Padat)(Dengan metode Stabilisasi dan Solidifikasi limbah B3 yang telah dilakukan di Amerika Serikat dan negara-negara lainnya sejak 50 tahun yang lalu. Proses stabilisasi dan solidifikasi ini dilakukan untuk menjamin bahwa sifatsifat kimia dan fisika limbah B3 yang diolah adalah sesuai dengan kriteria landfill); Liquid Waste Treatment (Pengolahan Limbah Cair)(Dengan metode Physical Chemical \& Biological Treatment yaitu instalasi pengolahan limbah cair, untuk mengolahan limbah cair sehingga menjadi non limbah dan telah sesuai dengan baku mutu air buangan); Waste to Energy (Pengolahan Limbah Menjadi Energi)(Fuels Blending adalah fasilitas pemanfaatan limbah menjadi energi yang telah beroperasi dari tahun 1994, dimana merubah limbah baik padat ataupun cair menjadi alternatif bahan bakar atau bahan baku untuk pabrik semen).

Pada gambaran fasilitas tidak tercantum fasilitas untuk pengelolaan dan pemusnahan limbah medis yaitu insenerator. Ini berarti PPLI belum memiliki fasilitas Insinerator untuk mengolah limbah medis walaupun dalam prakteknya saat ini PPLI juga melakukan aktifitas pengelolaan limbah medis dari beberapa penghasil seperti klinik, rumah sakit dan lainnya untuk mengelola limbah medis yang dihasilkan. Namun dalam pengelolaan tersebut PPLI hanya mampu berperan sebagai Pengangkut dan Pengumpul untuk kemudian pemusnahan limbah medisnya PPLI bekerjasama dengan pihak ketiga yang memiliki fasilitas insinerator. 


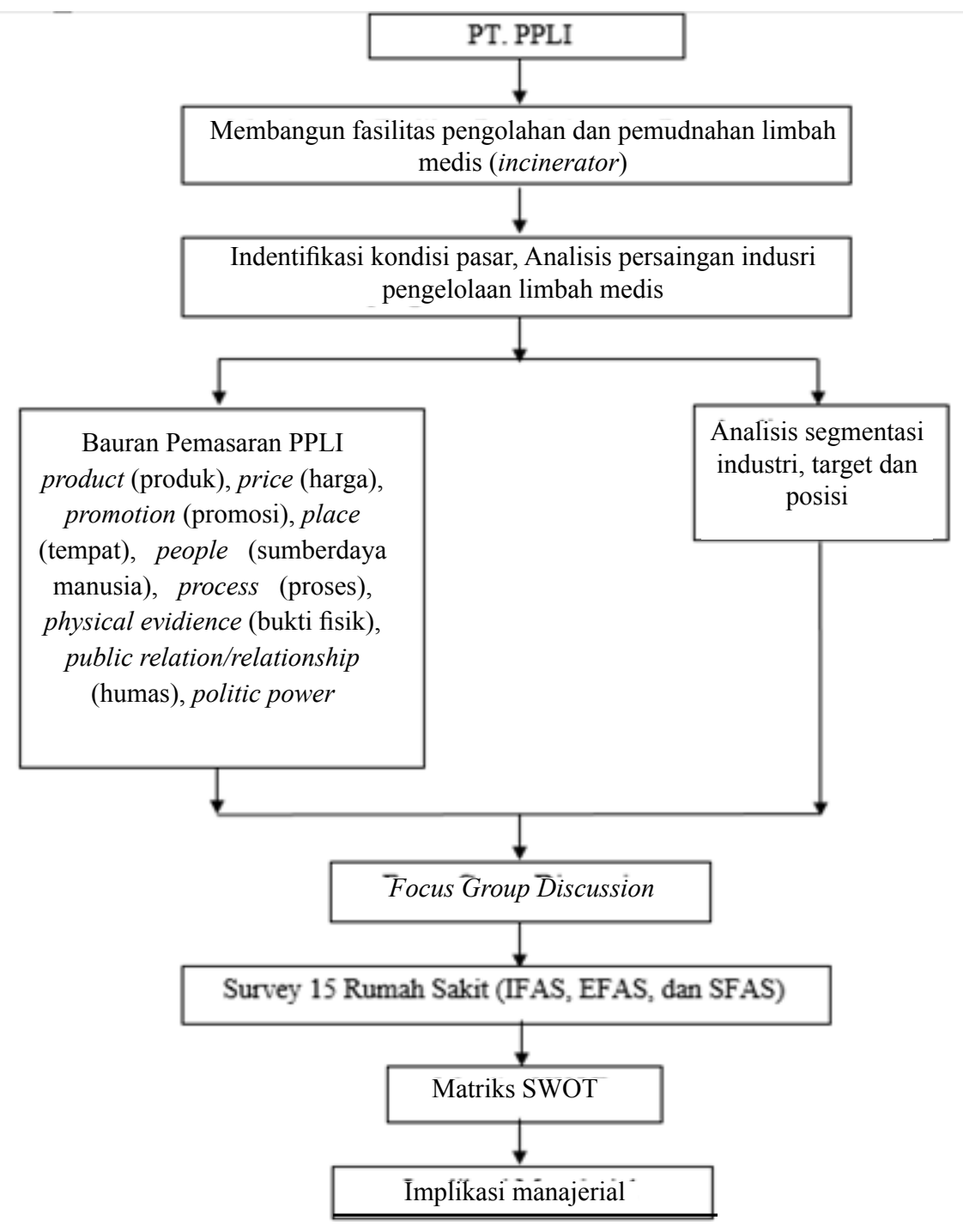

Gambar 1. Kerangka Pemikiran penelitian

\section{Identifikasi Segmentasi, Target dan Posisi}

Segmentasi dengan melihat karakteristik, daya tarik potensial segmen secara keseluruhan yaitu ukuran, pertumbuhan, profitabilitas, skala ekonomi dari penghasilan pelanggan dan mempertimbangkan tujuan dan sumber daya yang dimiliki (Febriyanti et al. 2019). Cara yang dilakukan PPLI untuk memulai kegiatan bisnis jasa pengolahan dan pemusnahan limbah medis, maka dilakukannya beberapa identifikasi. Seperti identifikasi segmentasi dimana dasar PPLI melakukan segmentasi adalah segmentasi kelas fasilitas pelayanan dan segmentasi geografis, dimana pada segmentasi kelas fasilitas pelayanan PPLI menetapkan keseluruhan fasilitas kesehatan baik rumah sakit kelas A hingga Non Kelas sampai ke puskesman dan klinik. Namun, untuk segmentasi geografis PPLI menetapkan segment geografis yaitu Jakarta, Bogor, Depok, Tanggerang dan Bekasi (JABODETABEK).
Identifikasi target, identifikasi target, PPLI menetapkan target pengolahan limbah medis pada tahap awal ini (setahun berjalannya insenerator PPLI) adalah 10.000 $\mathrm{kg}$ per hari yang bersumber dari 100 fasilitas pelayanan kesehatan yang tersebar di JABODETABEK. Target yang tidak terlalu muluk bila dibandingkan dengan fasilitas yang akan dibangun PPLI adalah incinerator dengan kapasitas 20 Ton per hari. Sehingga dari penetapan target dengan kapasitas yang dimiliki PPLI masih sangat mungkin dan dapat dicapai.

Yang terakhir adalah identifikasi posisi, dimana PPLI sendiri memposisikan diri sebagai perusahaan yang kompeten dan memiliki kemampuan dalam pengelolaan limbah B3 di Indonesia. Pengelolaan ini dimulai dari pengangkutan, pengumpulan, pengolahan, pemanfaatan, hingga pemusnahan akhir. Dan menjadi satu satunya perusahaan yang memiliki fasilitas pemusnahan akhir (landfill) di Indonesia. Hal ini pula yang menjadikan PPLI percaya mampu menguasai pasar limbah medis 


\section{Identifikasi Bauran Pemasaran}

Bauran pemasaran sebagai alat pemasaran yang banyak digunakan di abad 21 (Constantindes 2006). Pengaruh antara aktivitas-aktivitas pemasaran dengan daya tarik pelanggan dikemukakan Sumarwan et al. (2013) melalui teori ekuitas merek yang mengatakan bahwa ada pengaruh antara bauran pemasaran dengan kesadaran merek, kesan kualitas, dan loyalitas yang dikenal juga sebagai ekuitas merek. Rano et al. (2017) mengemukakan bahwa keadaan yang dapat dikendalikan adalah hal-hal yang berhubungan dengan keadaan usaha itu sendiri seperti bauran pemasaran sedangkan yang tidak dapat dikendalikan perusahaan antara lain, peraturan pemerintah, hukum yang berlaku, dan lain-lain. Menurut Kotler dan Amstrong (2008), bauran pemasaran adalah perangkat alat pemasaran yang digunakan untuk mengejar tujuan. Alat-alat tersebut dapat digunakan untuk menyusun strategi jangka panjang dan merancang program jangka pendek. Bauran pemasaran terdiri dari semua hal yang dapat dilakukan perusahaan untuk mempengaruhi permintaan produknya.dan unsur-unsur bauran pemasaran jasa terdiri dari tujuh peubah (9P), yaitu product (produk), price (harga), promotion (promosi), place (tempat), people (sumberdaya manusia), process (proses), physical evidience (bukti fisik), public relation/relationship (humas), politic power (pemerintah) dengan penjelasan sebagai berikut:

\section{Product (Aspek Produk)}

Produk adalah barang atau jasa yang dapat kamu tawarkan kepada para konsumen. Produk yang berkualitas yang kompetitif akan memberikan kesan positif kepada konsumen sehingga mereka tertatik untuk menggunakan produk yang kamu tawarkan. Para konsumen menggunakan suatu produk demi mendapat manfaat atas produk yang mereka beli. Di lain sisi, pengusaha mengasilkan produk/jasa untuk memberikan manfaat kepada konsumen yang menggunakan produknya dan memperoleh laba sebagai balas jasa. Begitu juga dengan PPLI yang berfokus kepada kemaksimalan pelayanan dan pemenuhan regulasi untuk memastikan pengelolan limbah medis dilakukan dengan benar dan baik untuk lingkungan.
Price (Aspek Harga)

Harga menjadi komponen penting dalam bauran pemasaran setelah kualitas produk yang baik. Hal tersebut dikarenakan harga menjadi pertimbangan penting kedua setelah manfaat atas produk yang ditawarkan. Harga produkyangterlalutinggiakanberdampaknegatifterhadap pertimbangan konsumen untuk membeli produk yang anda jual (karena merasa keberatan). Sebaliknya, Apabila harga produk terlalu terlalu rendah, memang berdampak positif terhadap pertimbangan konsumen dalam membeli produk yang anda tawarkan, namun berdampak negatif terhadap laba yang akan diperoleh. PPLI memilih untuk tidak bersaing dalam harga, dikarenakan kemampuan dan fokus PPLI untuk memberikan pelayanan dan jasa pengelolaan limbah medis dengan baik dan benar.

\section{Place (Aspek Tempat Lokasi)}

Aspek ini diartikan sebagai tempat lokasi usaha yang strategis dengan segala kebutuhan yang berpengaruh dalam aktifitas usaha baik itu produksi, pengadaan, pemasaran, manajerial, dan lain sebagainya. Menjadi penting bagi sebuah perusahaan untuk mempertimbangan dan menentukan tempat yang strategis bagi usahanya. Lokasi yang strategis disini dapat difahami sebagai suatu lokasi yang dekat dengan segala aspek dalam kegiatan usaha (produksi, pemasaran, pengadaan, dll) sehingga tidak mengeluarkan banyak biaya, tenaga, waktu, dan modal. PPLI hanya memiliki satu lokasi untuk mengolah limbah B3 dan limbah medis di seluruh Indonesia, hal ini berkaitan dengan studi kelayakan tempat dan fasilitas pengolahan dan pemusnahan ahir limbah B3 di Indonesia.

\section{Promotion (Aspek Promosi)}

Dalam sebuah definisi, promosi diartikan sebagai upaya untuk memberitahukan atau menawarkan produk atau jasa pada dengan tujuan menarik calon konsumen untuk membeli atau mengkonsumsinya. Aspek ini menjadi sangat penting dalam konsep pemasaran dan bauran pemasaran. Promosi yang baik adalah promosi yang disesuaikan dengan segmen pasar yang telah ditentukan diawal. Langkah promosi yang dilakukan PPLI untuk memperkenalkan jasa baru dalam pengelolaan limbah medis kepada para pelanggan masih bersifat personal dan langsung, dimana sales PPLI akan menyampaikan secara langsung detail produk, layanan, dan fasilitas yang tertuang dalam brosur pengelolaan limbah medis. 


\section{People (Aspek Partisipan)}

Aspek ini dapat dikatakan sebagai sumber daya manusia yang berpartisipasi dalam kegiatan usaha mulai dari pengadaan, produksi, dan pemasaran akhir. Dalam memberikan layanan maksimal keada pelangganya PPLI menempatkan sumber daya manusia yang telah dilatih kedalam satu departemen yaitu Field Service Departemen yang dipergunakan untuk melakukan aktifitas penanganan limbah medis yang meliputi pengemasan, penimbangan dan pemuatan limbah kedalam truk. Selain itu PPLI juga memiliki Customer Service dan Transport Department untuk memastikan pelanggan terlayanani dengan baik. Dan untuk komunikasi serta penjelasan yang terperinci yang merupakan pintu komunikasi antara pelanggan dengan PPLI, akan diwakili oleh Sales Department.

\section{Process (Aspek Proses)}

Aspek ini diartikan sebagai seberapa cakap sebuah perusahaan dalam menghasilkan produk dan memberikan pelayanan terhadap konsumennya sehingga mereka puas dengan apa yang perusahaan tersebut tawarkan. Alur pelayanan yang diberikan perusahaan dengan tuntutan kemudahan dari pelanggan dan kesesuaian dengan regulasi oleh pemerintah. Maka pada proses pelayanan untuk pengelolaan limbah medis yang akan diterapkan oleh PPLI dimulai dari limbah dihasilkan, persetujun kerja sama, kemasan yang digunakan, proses penimbangan, hingga pengangkutan dan akhirnya pemusnahan limbah medis yang keseluruhan prosesnya (PT. PPLI, 2019) tertuang pada Gambar 2.

\section{Physical Evidence (Bukti Fisik)}

Aspek ini dapat diartikan sebagai tampilan fisik suatu usaha yang meliputi bagaimana tampilan tempat usaha, tampilan produk, penampilan para pelayan, dan design pendukung lainnya. Dalam bauran pemasaran, aspek ini menjadi hal yang sangat penting untuk diperhatikan. Good view adalah langkah awal seorang konsumen untuk datang dan mencoba produk yang ditawarkan. Semakin bagus tampilan design secara keseluruhan, maka akan semakin banyak perhatian konsumen yang dapat diperolehkan. Bukti fisik yang ditunjukan PPLI mulai dari Sales PPLI dimana menggunakan ID card berlogo PPLI, menjelaskan dengan slide dan brosur pengelolaan limbah medis milik PPLI. Hingga box kemasan limbah medis dan truk khusus berpendingin -200 C, untuk mengangkut limbah medis tersebut untuk dimusnahkan pada incinerator limbah medis yang akan dibangun di home base PPLI.

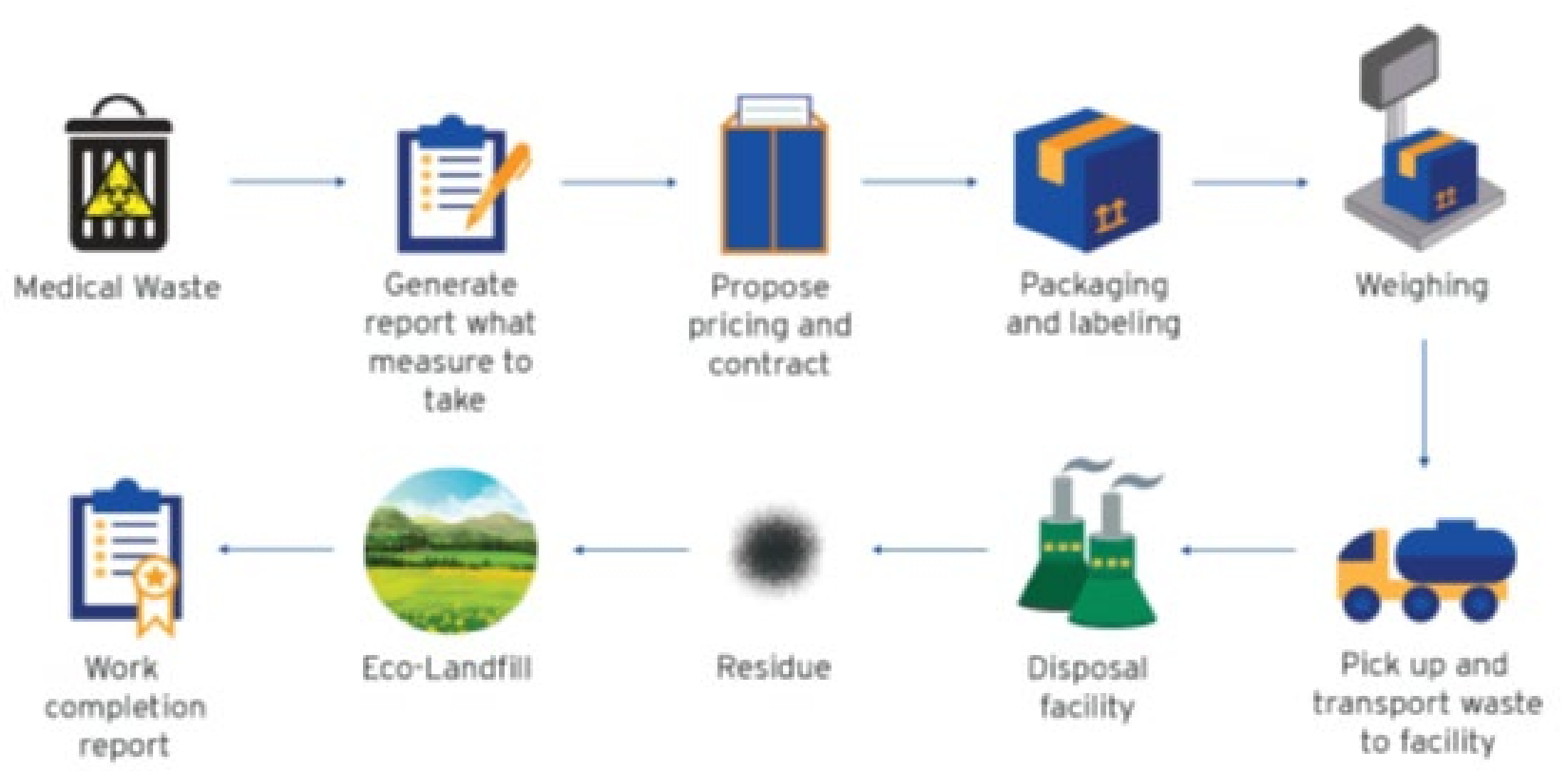

Gambar 2. Prosedur Pengelolaan Limbah Medis PPLI 
Dalam konsep marketing mix masa kini, hubungan baik yang terbangun dengan pengambil keputusan menjadi hal yang sangat penting untuk diperhatikan dan dibangun. Membangun opini pengambil keputusan memang tidaklah mudah. Bila melihat pamor dan kapasitas PPLI dalam pengelolaan limbah B3 non medis, dimana PPLI menjadi pilihan pertama untuk solusi semua limbah B3, maka PPLI sangat percaya diri untuk pengelolaan limbah medis juga akan medapatkan kepercayaan dari pengambil keputusan dalam hal ini penghasil limbah medis.

\section{Political Power (Kekuatan Politik)}

Aspek ini dapat diartikan sebagai kemampuan perusahaan dalam partisipasi untuk memenuhi regulasi dari kebijakan nasional maupun international yang memiliki pengaruh penting terhadap keberlangsungan suatu usaha. Seperti diketahui bahwa pemilik saham PPLI adalah pemerintah, yang seharusnya dapat dimaksimalkan untuk menguntungkan PPLI dalam hal kebijakan yang akan dibuat pemerintah untuk menjalankan bisnis pengelolaan dan pemusnahan limbah medis, namun untuk political power ini tidak digunakan sama sekali oleh PPLI, hubungan dan kordinasi dengan pemerintahan hanya sebatas pemenuhan kewajiban sebagai perusahaan pengelola limbah

\section{Faktor yang Berperan dan Berpengaruh dalam Strategi Pemasaran Pengelolaan Limbah Medis}

Berdasarkan wawancara kepada PPLI, KLHK, dan KEMENKES mengenai lini bisnis pengelolaan limbah medis ini maka dapat dicacat bahwa beberapa faktor yang menjadi penentu bisnis pengelolaan limbah medis dan mempengaruhi pemilihan strategi pemasaran pada PPLI. Dimulai dari regulasi pemerintah, dimana bisnis ini sepenuhnya diwajibkan untuk mengikuti regulasi yang telah ditetapkan oleh pemerintah. Adapun faktor penentu bisnis pengelolaan limbah medis adalah sebagai berikut:

\section{Regulasi Pemerintah}

Maksud dari regulasi pemerintah adalah seperangkat peraturan yang diterapkan oleh pemerintah. Dimana dalam penetapan peraturan pengelolaan limbah medis ini meliputi peraturan lingkungan dan juga kesehatan yang mengharuskan operasi pengelolaan limbah medis ini diawasi setiap rangkainnya, mulai dari dihasilkan, disimpan, diangkut, dikumpulkan, diolah hingga dimusnahkan. Untuk itulah PPLI akan menyesuaikan kegiatan operasi dengan aturan yang berlaku, karena regulasi pemerintah akan menjadi faktor penting yang harus diperhatikan PPLI dalam menjalankan kegiatan bisnis pengelolaan limbah medis, dan PPLI terbukti mampu memenuhi faktor ini sejak 1994 silam.

\section{Hubungan dengan Pengambil Keputusan}

Hubungan dengan pengambil keputusan merupakan faktor penting kedua dimana perusahaan dituntut untuk menjalin hubungan yang baik. Hubungan yang baik dan harmonis akan meningkatkan potensi keberhasilan sebuah usaha dari perusahaan tersebut.Hubungan tersebut meliputi koordinasi dan komunikasi yang terjalin erat dengan pemerintah selaku regulator serta pelanggan, dalam hal ini adalah subbidang Kesehatan Lingkungan di fasilitas pelayanan kesehatan.

\section{Tren Pasar}

Tren pasar merupakan factor yang penting. Ini dikarenakan pasar sangat berkembang dan dinamis dimana dengan kebutuhan pelayan yang lebih komplek sehingga tuntutan penghasil limbah medis (konsumen) memaksa PPLI atau perusahaan sejenis untuk menciptakan suata cara yang memudahkan konsumen dari segala sesuatu mengenai pengelolaan limbah medis yang ia hasilkan. Tren pasar juga berbicara mengenai biaya yang dikeluarkan, dengan biaya yang efisien namun dapat memenuhi syarat dan ketentuan dari regulasi yang berlaku.

\section{Teknologi Pengelolaan Limbah Medis}

Faktor penting dalam bisnis pengelolaan limbah medis ini adalah teknologi insenerator. Adapun emisi, kapasitas dan kepastian limbah dimusnahkan dengan benar. Untuk itulah PPLI akan membangun teknologi insenerator yang mengadopsi teknologi dari Jepang, dengan kapasitas yang besar dan timbulan emisi yang dibawah ambang batas regulasi pemerintah Indonesia.

\section{Pengalaman Perusahaan}

Pengalaman PPLI dalam pengelolaan limbah B3 merupakan faktor penting dalam penentuan strategi pemasaran saat ini. Konsumen menganggap perusahaan yang lebih banyak sisi pengalamannya akan lebih unggul 
dari perusahaan lain yang sejenis. PPLI yang merupakan perusahaan pertama dalam pengelolaan limbah B3 di Indonesia sangat yakin mampu menguasai pasar limbah medis.

\section{Identifikasi Aktor Penentu Bisnis Pengelolaan Limbah Medis}

Aktor-aktor yang juga merupakan pemangku wewenang sebagai penentu bisnis pengelolaan limbah medis dan mempengaruhi PPLI dalam pemilihan strategi pemasaran yang merupakan penilaian dari pakar-pakar/ahli dalam pengelolaan limbah medis, mulai dari regulasi, teknologi, hingga penilaian terhadap pemasaran.

Kementerian Lingkungan Hidup dan Kehutanan (KLHK)

Aktor di lingkup Kementerian Lingkungan Hidup dan Kehutanan meliputi Direktur verifikasi pengelolaan limbah B3 dan Non B3, Dirjen pengelolaan sampah, limbah dan B3 hingga ke Dinas Lingkungan Hidup tingkat provinsi dan kabupaten. Aktot tersebut memegang penuh wewenang untuk melakukan pengawasan dan pendidikan kepada seluruh elemen yang terlibat dalam mata rantai pengelolaan limbah medis, mulai dari fasilitas kesehatan, perusahaan transporter, pengumpul hingga perusahaan pemusnahan yang memiliki fasilitas insenerator. Melalui organisasi dibwah KLHK maka kepastian limbah dikelola dengan baik dengan pengawasan meyeluruh akan dapat dicapai.

\section{Kementerian Kesehatan (Kemenkes)}

Aktor di lingkup Kementerian Kesehatan meliputi Direktur Kesehatan Lingkungan, Ditjen Kesehatan Pengambil keputusan yang menetapkan regulasi pengendalian kesehatan lingkungan meliputi buangan yang dihasilkan fasilitas kesehatan di Indonesia baik sampah, limbah medis, dan juga limbah B3 yang senantiasa dipantau, dicatat dan diawasi pengelolaannya. Kemenkes merupakan aktor penentu bisnis pengelolaan limbah medis karena seluruh fasilitas Kesehatan di Indonesia mengikuti aturan dan regulasi yang dikeluarkannya. Melalui organisasi dibawah Kemenkes maka kepastian limbah medis untuk dikelola dengan baik akan lebih mudah tercapai.

\section{PPLI}

Aktor di lingkup PPLI meliputi Direktur Sales dan Marketing yang merancang strategi pemasaran yang akan diterapkan untuk mencapai tujuan dan juga bertanggung jawab atas pelayanan kepada konsumen. PPLI yang merupakan penantang baru dalam bisnis peyediaan jasa pengelolaan limbah medis berencana membuat sebuah department sales khusus untuk mengaplikasi rancangan dan strategi pemasaran. Direktur Sales dan Marketing juga akan menetapkan target fasilitias kesehatan yang akan dimaksimalkan penetrasinya oleh PPLI.

\section{Identifikasi Tujuan Dalam Penyusunan Strategi Pemasaran}

Menurut David (2011), perumusan strategi pemasaran adalah pengembangan rencana jangka panjang untuk manajemen efektif dari peluang dan ancaman lingkungan, dilihat dari kekuatan dan kelemahan perusahaan. Hal yang perlu diperhatikan di sini adalah bagaimana perusahaan mengambil inisiatif untuk merubah cara pelayanan-nya agar dapat menyesuaikan diri dengan lingkungan di luar perusahaan yang menghendaki perubahan (Angelica, 2016). Adapun tujuan yang ingin dicapai oleh PPLI dalam pemilihan strategi pemasaran, yaitu antara lain:

\section{Peningkatan Profit Perusahaan}

PPLI yang telah menguasai pasar pengelolaan limbah B3 di Indonesia harus memiliki sebuah cara yang baru untuk meningkatkan profit perusahaanya. Maka dari itu pendirian fasilitas baru yang juga berarti sebuah tantangan baru bagi PPLI. Untuk itu meningkatkan penjualan untuk profit merupakan salah satu tujuan yang wajib dicapai oleh PPLI.

\section{Memperluas Pangsa Pasar}

Pangsa pasar PPLI yang sangat terbatas untuk pengelolaan limbah medis merupakan tantangan sekaligus salah satu tujuan yang ingin diraih PPLI saat ini. Hal ini sangat mungkin dapat terpenuhi dalam waktu yang relatif singkat. Mengingat PPLI memiliki perangkat untuk menguasai pasar pengelolaan limbah medis seperti tempat pengumpulan limbah, truk-truk khusus pengangkut limbah medis dan juga sumber daya manusia terlatih untuk menangani limbah secara professional. Melengkapi Fasilitas Pengolahan Limbah B3

Untuk menyempurnakan jasa pengolahan limbah B3 yang ditawarkan PPLI dimana seluruh limbah B3 dapat dikelola secara terpadu. Maka PPLI harus memiliki fasiitas insenerator. Sehingga ini akan menjadikan PPLI 
satu-satunya perusahaan pengolahan limbah B3 yang terpadu di Indonesia serta PPLI dapat menjadi perusahaan yang terlengkap fasilitasnya dalam pengelolaan limbah B3 di Indonesia.

\section{Analisis SWOT}

Berdasarkan Permenkes RI No. 340 tahun 2011, mengenai klasifikasi rumah sakit yaitu tipe rumah sakit A, B, C, D dan NonD (MENKES, 2011). Kondisi dan situasi pengelolaan limbah medis di Indonesia yang berdasarkan data dan informasi yang diolah dari Kementerian Kesehatan Republik Indonesia dan Kementrian Lingkungan Hidup dan Kehutanan, bahwa limbah medis yang dihasilkan dari 2813 Rumah Sakit berjumlah 233.210 kg/hari (Tabel 1). Dengan area penghasil limbah medis terbesar berada diwilayah Banten-DKI Jakarta-Jawa Barat lalu diikuti oleh Jawa Tengah dan Jawa Timur.

Kondisi Pasar
Mengenai kondisi pasar, didapatkan informasi penting adalah mengenai share market (pembagian pasar) untuk pengelolaan limbah medis yang dilakukan oleh Rumah Sakit sendiri secara mandiri atau oleh perusahaan swasta. Dimana dari total limbah yang dihasilkan sebanyak 233 ton per hari yang pembagian pengelolaanya adalah sebesar 59\% dikelola oleh 12 perusahaan swasta dengan total sehari limbah medis yang dikelola sebanyak 138,22 ton dan berikutnya sebesar $17 \%$ dikelola pada 82 fasilitas pelayanan kesehatan dengan total sehari limbah medis yang dikelola sebanyak 39,49 ton, sehingga bersisa sebanyak 55,29ton atau sebesar $24 \%$ limbah medis yang tidak dikelola dengan benar. Selain diagram share market (pembagian pasar) diatas didapatkan juga informasi penting terhadap harga. Dimana harga merupakan bagian yang tidak dapat dipisahkan dalam strategi pemasaran, karenanya informasi mengenai harga pasar yang didapatkan ini menjadi pertimbangan PPLI untuk merumuskan strategi pemasaran nantinya. Adapun harga pengelolaan limbah medis dipulau jawa Tabel 2.

Tabel 1. Data dan informasi Rumah Sakit di Indonesia

\begin{tabular}{|c|c|c|c|c|c|c|c|c|c|}
\hline \multirow{2}{*}{ No } & \multirow{2}{*}{ LOKASI } & \multicolumn{4}{|c|}{ Rumah Sakit } & \multicolumn{4}{|c|}{ ESTIMASI LIMBAH KG /HARI } \\
\hline & & $\mathrm{A}$ & $\mathrm{B}$ & $\mathrm{C}$ & Dnd & A & $\mathrm{B}$ & $\mathrm{C}$ & Dnd \\
\hline A & Aceh - Sumut & 4 & 39 & 149 & 86 & 800 & 3.900 & 7.450 & 2.580 \\
\hline B & Riau-Sumbar-Jambi & 3 & 23 & 133 & 65 & 600 & 2.300 & 6.650 & 1.950 \\
\hline $\mathrm{C}$ & Sumsel-Lampung- Bengkulu & 3 & 18 & 118 & 63 & 600 & 1.800 & 5.900 & 1.890 \\
\hline $\mathrm{D}$ & Banten-Jakarta-Jawa Barat & 26 & 150 & 358 & 131 & 10.400 & 25.500 & 35.800 & 9.170 \\
\hline $\mathrm{E}$ & Jawa Tengah & 12 & 45 & 160 & 155 & 4.800 & 7.650 & 16.000 & 10.850 \\
\hline $\mathrm{F}$ & Jawa Timur - Ntb - Bali & 8 & 73 & 262 & 189 & 2.800 & 10.950 & 26.200 & 9.450 \\
\hline G & Kalimantan & 4 & 22 & 105 & 51 & 800 & 2.200 & 5.250 & 1.530 \\
\hline $\mathrm{H}$ & Sulawesi & 3 & 39 & 146 & 109 & 600 & 3.900 & 7.300 & 3.270 \\
\hline \multirow[t]{3}{*}{ I } & Papua & & 2 & 20 & 39 & & 200 & 1.000 & 1.170 \\
\hline & TOTAL & 63 & 411 & 1,451 & 888 & 21400 & 58400 & 111550 & 41860 \\
\hline & & \multicolumn{4}{|c|}{$2.813 \mathrm{RS}$} & \multicolumn{4}{|c|}{$233,210 \mathrm{KG} / \mathrm{HARI}$} \\
\hline
\end{tabular}

Tabel 2. Rangkuman harga Area Jawa

\begin{tabular}{lcc}
\hline Area & Quantity & Est Price / Kg \\
\hline Banten & 31.248 & 9.900 \\
Banten & 93.22 & 6.705 \\
Banten & 41.100 & 5.278 \\
Banten & 30.000 & 6.893 \\
Banten & 110.150 & 8.193 \\
Jawa Tengah & 675.714 & 8.998 \\
Jawa Tengah & 268.860 & 7.155 \\
Jawa Tengah & 82.620 & 6.524 \\
DKI Jakarta & 25.000 & 8.306 \\
DKI Jakarta & 26.121 & 7.950 \\
DKI Jakarta & 825.364 & 6.335 \\
DKI Jakarta & 28.000 & 4.500 \\
\hline
\end{tabular}

\begin{tabular}{lcc}
\hline Area & Quantity & Est Price / Kg \\
\hline DKI Jakarta & 143.076 & 5.121 \\
Jawa Timur & 45.000 & 8.775 \\
Jawa Timur & 52.195 & 8.549 \\
Jawa Timur & 127.750 & 8.217 \\
Jawa Timur & 12.000 & 15.060 \\
Jawa Timur & 35.841 & 17.820 \\
Jawa Timur & 24.000 & 14.850 \\
Jawa Barat & 219.000 & 6.615 \\
Jawa Barat & 21.866 & 9.874 \\
Jawa Barat & 340.848 & 8.873 \\
Jawa Barat & 30.000 & 7.624 \\
Jawa Barat & 40.050 & 10.048 \\
\hline
\end{tabular}


Dengan melihat kondisi dan situasi market yang ada maka sangat besarlah peluang PPLI untuk sukses dalam lini bisnis barunya ini, yaitu pengolahan dan pemusnahan limbah medis ini, selain karena potensi jumlah limbah yang dihasilkan juga lebar, karena market share yang masih terbuka Dimana potensi sebesar $24 \%$ untuk area yang belum dikelola dengan baik dapat dimanfaatkan semaksimal mungkin oleh PPLI untuk mengelola limbah medis dengan efektif sesuai regulasi dan efisien sesuai dengan keinginan dan harapan penghasil limbah medis di Indonesia.
Berdasarkan wawancara dan diskusi tersebut didapatlan key success factor yang tertuang dalam faktor kekuatan, kelemahan, peluang dan ancaman bagi PPLI dalam menentukan strategi pemasaran pada bisnis pengelolaan limbah medis ini. Ada 5 Kekuatan, 5 Kelemahan PPLI yang menjadikannya sebagai internal factor analysis strategy (IFAS)(Tabel 3), serta ada 4 Peluang, 4 Ancaman bagi PPLI yang menjadikannya sebagai external factor analysis strategy (EFAS) (Tabel 4).

Table 3. Hasil Internal Factor Analysis Strategy (IFAS)

\begin{tabular}{llll}
\hline Kekuatan (Strengths) & Bobot & Rating & Skor \\
\hline PPLI sangat mematuhi dan memenuhi peraturan pengelolaan limbah medis di Indonesia & 0,15 & 4,07 & 0,61 \\
PPLI memberikan pelayanan mulai dari pengemasan, pengangkutan, pengumpulan, hingga & 0,1 & 4,47 & 0,45 \\
pemusnahan & & & \\
PPLI memiliki armada pengangkutan sendiri (truk berpendingin) & 0,1 & 4,53 & 0,45 \\
PPLI terbuka untuk diaudit langsung & 0,05 & 4,20 & 0,21 \\
PPLI terkenal, terpercaya dan terbaik dalam pengelolaan limbah B3 di Indonesia & 0,1 & 4,53 & 0,45 \\
\hline TOTAL & 2,17 & & \\
\hline Kelemahan (Weakness) & Bobot & Rating & Skor \\
\hline Biaya pengelolaan limbah medis PPLI diatas Rp. 10.000 per Kg & 0,15 & 2,87 & 0,43 \\
PPLI bekerjasama dengan pihak ketiga untuk pengemasan, pengangkutan, pengumpulan, dan & 0,1 & 3,47 & 0,35 \\
pemusnahan & & & \\
PPLI tidak dapat menjadwalkan pengangkutan setiap hari & 0,1 & 3,33 & 0,33 \\
PPLI tidak dapat diaudit tanpa ada surat pemberitahuan sehari sebelumnya & 0,05 & 3,00 & 0,15 \\
PPLI belum memiliki pengalaman pemusnahan limbah medis hingga insenerator dibangun & 0,1 & 3,13 & 0,31 \\
\hline TOTAL & 1,57 & & \\
\hline NILAI IFAS = TOTAL Kekuatan - TOTAL Kelemahan & \multicolumn{3}{l}{0,60} \\
\hline
\end{tabular}

Table 4. Hasil External Factor Analysis Strategy (EFAS)

\begin{tabular}{|c|c|c|c|}
\hline Peluang (Opportunities) & Bobot & Rating & Skor \\
\hline Regulasi dan peraturan pengelolaan limbah medis sangat ketat & 0,15 & 4,47 & 0,67 \\
\hline $\begin{array}{l}\text { Jumlah Rumah Sakit dan Fasilitas Pelayanan Kesehatan yang bertambah (Pasar limbah medis } \\
\text { sangat luas dan terbuka) }\end{array}$ & 0,15 & 4,47 & 0,67 \\
\hline $\begin{array}{l}\text { Pengurus FASYANKES membutuhkan perusahaan yang terpecaya dalam mengelola limbah } \\
\text { medis }\end{array}$ & 0,1 & 4,53 & 0,45 \\
\hline $\begin{array}{l}\text { KLHK dan KEMENKES senantiasa melakukan audit kepada FASYANKES untuk kebijakan } \\
\text { lingkungan dalam hal pengelolaan limbah medis }\end{array}$ & 0,1 & 4,40 & 0,44 \\
\hline TOTAL & 2,23 & 4,53 & 0,45 \\
\hline Ancaman (Threats) & Bobot & Rating & Skor \\
\hline $\begin{array}{l}12 \text { perusahaan swasta yang memiliki insenerator telah memberikan pelayanan kepada } \\
\text { FASYANKES }\end{array}$ & 0,15 & 3,33 & 0,50 \\
\hline $\begin{array}{l}\text { Transporter (perusahaan pengangkutan limbah medis) mendukung penuh } 12 \text { Perusahaan } \\
\text { Swasta tersebut }\end{array}$ & 0,15 & 3,40 & 0,34 \\
\hline $\begin{array}{l}\text { Opini Pengurus FASYANKES untuk biaya (harga) pengolahan limbah medis sudah terbentuk } \\
\text { tetap }\end{array}$ & 0,1 & 3,60 & 0,54 \\
\hline $\begin{array}{l}\text { Auditor dari KLHK dan KEMENKES belum dapat menjanggkau seluruh FASYANKES di } \\
\text { Indonesia }\end{array}$ & 0,1 & 3,07 & 0,31 \\
\hline TOTAL & 1,69 & 3,00 & 0,15 \\
\hline NILAI EFAS = TOTAL Peluang - TOTAL Ancaman & & & 0,55 \\
\hline
\end{tabular}


Berdasarkan hasil IFAS, yaitu sebesar 0,60 dan EFAS sebesar 0,55. Maka kita dapat menentukan posisi PPLI pada kuadrat SWOT. Dan terlihat posisi PPLI dalam kuadran SWOT berada pada kuadran SATU. Tahapan selanjutnya adalah membuat table SFAS (Tabel 5).
Dimana tabel SFAS ini meringkas faktor-faktor kekuatan, kelemahan, peluang dan ancaman menjadi summary. Dari faktor-faktor tersebut yang disusun berdasarkan prioritas PPLI untuk mendapatkan tujuan yang ingin dicapai PPLI.

Table 5. Summary Factor Analysis Strategy (SFAS)

\begin{tabular}{|c|c|c|c|c|c|c|c|c|}
\hline SFAS & $\begin{array}{l}\text { Faktor-Faktor Strategis } \\
\text { (Pilihan yang paling } \\
\text { penting dari faktor } \\
\text { EFAS dan faktor IFAS) }\end{array}$ & Bobot & Rating & Skor & $\begin{array}{l}\frac{y}{0} \\
\frac{D}{0} \\
0\end{array}$ & 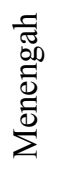 & : & Keterangan \\
\hline $\mathrm{S} 1$ & $\begin{array}{l}\text { PPLI sangat mematuhi } \\
\text { dan memenuhi } \\
\text { peraturan pengelolaan } \\
\text { limbah medis di } \\
\text { Indonesia }\end{array}$ & 0,15 & 4,07 & 0,61 & 0 & 0 & $\sqrt{ }$ & $\begin{array}{l}\text { PPLI senantiasa mematuhi dan } \\
\text { mengembangkan kopentsi untuk } \\
\text { memberikan masukan kepada Pemerintah } \\
\text { dalam membuat peraturan yang mampu } \\
\text { menjaga lingkungan Indonesia secara } \\
\text { efektif dan effisien }\end{array}$ \\
\hline $\mathrm{S} 2$ & $\begin{array}{l}\text { PPLI memberikan } \\
\text { pelayanan mulai } \\
\text { dari pengemasan, } \\
\text { pengangkutan, } \\
\text { pengumpulan, hingga } \\
\text { pemusnahan }\end{array}$ & 0,1 & 4,47 & 0,45 & $\sqrt{ }$ & o & $\mathrm{O}$ & $\begin{array}{l}\text { Akan menjadikan PPLI berbeda dengan } \\
\text { perusahaan pengelola limbah medis lainnya, } \\
\text { dan dalam waktu yang relative singkat } \\
\text { ini akan menjadi trend mark yang harus } \\
\text { di aplikasikan oleh perusahaan pengolah } \\
\text { limbah medis bila ingin bertahan dalam } \\
\text { bisnis ini }\end{array}$ \\
\hline W1 & $\begin{array}{l}\text { Biaya pengelolaan } \\
\text { limbah medis PPLI } \\
\text { diatas Rp. } 10.000 \text { per } \\
\text { Kg }\end{array}$ & 0,15 & 2,87 & 0,43 & o & $\sqrt{ }$ & $\sqrt{ }$ & $\begin{array}{l}\text { Hal ini menjadi salah satu kelemahan besar } \\
\text { PPLI yang belum dapat diaplikasikan } \\
\text { dalam waktu singkat mengingat biaya } \\
\text { investasi dan aplikasi pelayanan yang jauh } \\
\text { berkualitas dari perusahaan yang telah eksis }\end{array}$ \\
\hline W2 & $\begin{array}{l}\text { PPLI bekerjasama } \\
\text { dengan pihak ketiga } \\
\text { untuk pengemasan, } \\
\text { pengangkutan, } \\
\text { pengumpulan, dan } \\
\text { pemusnahan }\end{array}$ & 0,1 & 3,47 & 0,35 & o & o & $\sqrt{ }$ & $\begin{array}{l}\text { Untuk melayanani FASYANKES secara } \\
\text { maksimal, transportasi adalah bahagian } \\
\text { yang tak akan terpisahkan untuk diserahkan } \\
\text { kepada pihak ketiga. Butuh waktu yang } \\
\text { Panjang untuk dapat sepenuhnya dilakukan } \\
\text { oleh PPLI }\end{array}$ \\
\hline $\mathrm{O} 1$ & $\begin{array}{l}\text { Regulasi dan peraturan } \\
\text { pengelolaan limbah } \\
\text { medis sangat ketat }\end{array}$ & 0,15 & 4,47 & 0,67 & o & o & $\sqrt{ }$ & $\begin{array}{l}\text { PPLI berkomitmen tinggi untuk mematuhi } \\
\text { regulasi dan peluang ini akan menjadi } \\
\text { keuntungan jangka Panjang bagi PPLI }\end{array}$ \\
\hline $\mathrm{O} 2$ & $\begin{array}{l}\text { Pasar limbah medis } \\
\text { sangat luas dan terbuka }\end{array}$ & 0,1 & 4,47 & 0,45 & $\sqrt{ }$ & o & o & $\begin{array}{l}\text { Peluang terbukanya pasar dan ceruk antara } \\
\text { permintaan dengan penawaran masih sangat } \\
\text { besar untuk dapat dimanfaatkan dalam } \\
\text { waktu singkat oleh PPLI }\end{array}$ \\
\hline $\mathrm{T} 1$ & $\begin{array}{l}12 \text { perusahaan swasta } \\
\text { yang memiliki } \\
\text { insenerator telah } \\
\text { memberikan pelayanan } \\
\text { kepada FASYANKES }\end{array}$ & 0,1 & 3,33 & 0,33 & $\sqrt{ }$ & o & o & $\begin{array}{l}\text { PPLI memilih untuk menjalin kerjasama } \\
\text { yang saling menguntungkan dengan } \\
\text { perusahaan pengelolaan limbah medis, } \\
\text { sehingga kelemahan ini dapat diminimalisir } \\
\text { dalam waktu singkat oleh PPLI }\end{array}$ \\
\hline T3 & $\begin{array}{l}\text { Opini Pengurus } \\
\text { FASYANKES } \\
\text { untuk biaya (harga) } \\
\text { pengolahan limbah } \\
\text { medis sudah terbentuk } \\
\text { tetap }\end{array}$ & 0,15 & 3,60 & 0,54 & o & $\sqrt{ }$ & $\sqrt{ }$ & $\begin{array}{l}\text { Dengan merubah paradigma serta } \\
\text { aplikasi pengelolaan medis maka opini } \\
\text { ini akan berubah seiringnya waktu dalam } \\
\text { pengelolaan limbah medis }\end{array}$ \\
\hline & NILAI & 1 & & 3,82 & & & & \\
\hline
\end{tabular}


Berdasarkan hasil IFAS, EFAS dan SFAS diatas maka disusunlah matrik Analisis. Matrik Analisis ini bertujuan untuk memudahkan manajerial PPLI dalam merumuskan strategi pemasaran yang akan dilakukan. Rumusan analisis tersebut tertuang pada matriks TOWS (Tabel 6).

\section{Implikasi Manajerial}

Berdasarkan pemaparan total nilai IFAS berada pada angka 0.60 dan EFAS berada pada angka 0.55, hal ini dapat diartikan bahwa faktor strategy internal PPLI lebih besar pengaruhnya dibandingkan dengan faktor eksternal, dan terlihat pada tabel SFAS dimana PPLI Menyusun strategi pemasarannya terhadap faktor penting dan mencatat masa waktu terhadap strategi tersebut, dan berdasarkan paparan keseluruhan yang tercantum pada matriks SWOT, diperolehlah rekomendasi strategi untuk di implikasikan oleh manajemen PPLI. Yang pertama adalah strategi S-O (Strength-Opportunity) dimana PPLI yang berada pada kuadran satu haru secara maksimal mengoptimalkan kapasitas incinerator yang dimiliki, kemudian menggarap pasar rumah sakit se-JABODETABEK untuk semua kelas. Memastikan semua limbah non medis yang dihasilkan oleh rumah sakit dikelola penuh oleh PPLI. Melakukan investasi penuh dan maksimal untuk mempercepat beroperasinya incinerator dan penambahan armada pengangkutan PPLI untuk dapat memenuhi harapan pengurus Fasyankes (Fasilitas pelayanan kesehatan) bahwa limbah medis mereka diangkut secara rutin.

Tabel 6. Matriks TOWS

\begin{tabular}{|c|c|c|}
\hline & $\begin{array}{l}\text { Opportunity } \\
\text { 1. Regulasi dan peraturan ketat } \\
\text { 2. Pasar limbah medis luas dan } \\
\text { terbuka } \\
\text { 3. Pengurus Fasyankes membutuhkan } \\
\text { perusahaan yang terpercaya }\end{array}$ & $\begin{array}{l}\text { Threats } \\
\text { 1. } 12 \text { competitor telah melayani } \\
\text { Fasyankes } \\
\text { 2. Transporter limbah medis } \\
\text { mendukung competitor } \\
\text { 3. Opini pasar untuk harga telah } \\
\text { terbentuk dan tetap }\end{array}$ \\
\hline $\begin{array}{l}\text { Strengths } \\
\text { 1. Mematuhi dan memenuhi regulasi } \\
\text { 2. Pelayanan Prima mulai dari } \\
\text { pengemasan hingga kapasitas } \\
\text { pemusnahan } 50 \text { ton per hari } \\
\text { 3. Terkenal terpercaya dan terbaik } \\
\text { dalam pengelolaan limbah B3 }\end{array}$ & \begin{tabular}{|l} 
Strengths - Opportunity \\
1. \\
Menggarap pasar rumah sakit \\
JABODETABEK semua kelas \\
dengan mengoptimalkan kapasitas \\
2. Memastikan semua limbah \\
non medis/ non infeksius milik \\
fasyankes dikelola oleh PPLI \\
3. Melakukan Investasi maksimal \\
untuk mempercepat Insinerator siap \\
beroperasi dan juga penambahan \\
armada untuk pengangkutan rutin
\end{tabular} & $\begin{array}{l}\text { Strengths - Threats } \\
\text { 1. Bekerjasama dengan competitor } \\
\text { dan transporter untuk pengelolaan } \\
\text { limbah medis } \\
\text { 2. Mengunci competitor melalui hasil } \\
\text { insenerator berupa "abu" yang } \\
\text { harus di landfill } \\
\text { 3. Menetapkan harga batas bawah } \\
\text { Bersama dengan competitor untuk } \\
\text { pengelolaan limbah medis }\end{array}$ \\
\hline $\begin{array}{l}\text { Weakness } \\
\text { 1. Harga PPLI diatas } 10.000 \text { per kg } \\
\text { (harga mahal) } \\
\text { 2. Tidak ada department dan sistem } \\
\text { pelayanan khusus limbah medis } \\
\text { 3. Belum memiliki pengalaman } \\
\text { pemusnahan limbah medis }\end{array}$ & 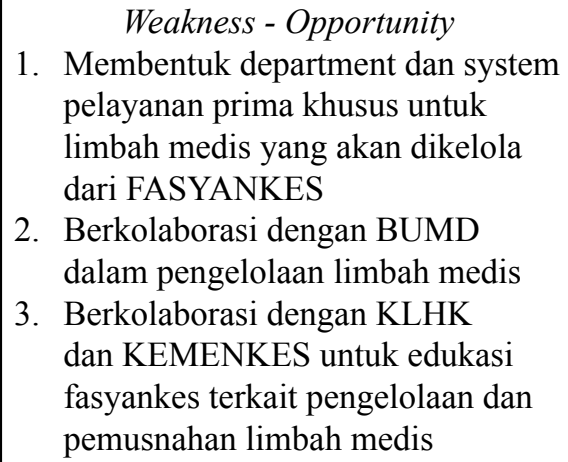 & $\begin{array}{l}\text { Weakness -Threats } \\
\text { 1. Membeli perusahaan competitor } \\
\text { untuk merebut pasar pengelolaan } \\
\text { limbah medis } \\
\text { 2. Mempromosikan teknologi } \\
\text { incinerator PPLI salah satu terbaik } \\
\text { di dunia }\end{array}$ \\
\hline
\end{tabular}


Strategi S-T (Strength-Threat) dengan bekerjasama langsung kepada competitor atau peyedia jasa pengelolaan limbah medis dan transporter untuk pengelolaan limbah medis. Mengunci competitor movement atau langkah perusahaan lain melalui hasil incinerator competitor yang berupa "abu" dan harus di landfill, dengan meningkatkan posisi PPLI terhadap competitor yang menjadi patner kerjasamanya. Dan terkahir strategi pada posisi ini adalah dengan menetapkan harga batas bawah bersama dengan competitor untuk pengelolaan limbah medis.

Strategi W - O (Weakness Opportunity) dengan membuat department khusus untuk pelayanan dan pengelolaan limbah medis di PPLI. Berkolaborasi dengan BUMD dalam pengelolaan limbah medis di daerah. Berkolaborasi dengan KLHK dan KEMENKES untuk mengedukasi fasyankes terkait regulasi dan kedisiplinan dalam hal pengelolaan dan pemusnahan limbah medis.

Strategi W-T (Weakness Threat) adalah strategi terakhir dengan posisi terendah yang dialami PPLI. Strateginya adalah dengan cara membeli perusahaan milik competitor untuk sepenuhnya dapat merebut pasar pengelolaan medis yang sudah dimiliki competitor. Mempromosikan teknologi incinerator PPLI secara massive keseluruh fasyankes bahwa incinerator PPLI adalah salah satu yang terbaik di didunia

\section{KESIMPULAN DAN SARAN}

\section{Kesimpulan}

Hasil pembahasan dan analisis diperoleh beberapa kesimpulan antara lain faktor-faktor yang berpengaruh dalam pemilihan strategi pemasaran saat ini, yaitu: regulasi pemerintah, hubungan dengan pengambil keputusaan, tren pasar, teknologi pengelolaan limbah medis dan pengalaman perusahaan PPLI yang baru dalam bisnis pengolahan limbah medis ini.

Aktor-aktor yang memengaruhi dalam pemilihan strategi pemasaran saat ini, yaitu KLHK dan KEMENKES, dalam hal ini dua regulator ini sangat menentukan strategi pemasaran PPLI yang akan dibuat oleh DIREKTUR SALES and MARKETING, berdasarkan kebijakan dan arahan yang diberikan dua komponen regulator tersebut untuk pengelolaan limbah medis pada FASYANKES di Indonesia.
Tujuan yang ingin dicapai oleh PPLI yaitu meningkatkan profit perusahaan, memperluas pangsa pasar dan melengkapi fasilitas pengolahan limbah B3 pada PPLI, sehingga jargon "integrated hazardous waste management (pengelolaan limbah B3 terpadu)" di Indonesia dapat terpenuhi secara maksimal.

Dalam mencapai tujuan utamanya PPLI diharuskan untuk memaksimalkan semua kemampuan dan mengeluarkan semua kekuatan serta sumberdaya yang dimiliki baik tenaga profesionalnya maupun investasi nya untuk mempercepat penroperasian insenerator sehingga PPLI dapat menguasai pasar pengelolaan limbah medis di Indonesia.

\section{Saran}

PPLI disarankan untuk menembus pasar fasyankes kelas C, D dan non kelas, hal ini karena curuk pasar sebesar $24 \%$ berada pada kelas FASYANKES tersebut. Pada kelas A dan B disarankan PPLI menggandeng BUMD ataupun senantiasa berkomunikasi dan berkolaborasi dengan Pemerintah Daerah setempat dalah hal ini Dinas Lingkungan Hidup dan Dinas Kesehatan untuk dapat melayani secara keseluruhan limbah yang dihasilkan pada FASYANKES kelas A dan B tersebut. Terobosan maksimal yang dapat dilakukan PPLI adalah memanfaatkan kemampuan, pengalaman serta sumber daya manusia dalam hal ini tenaga ahli untuk masuk dengan cara memberikan layanan non medis terlebih dahulu kepada FASYANKES yang memiliki loyalitas kuat kepada perusahaan pengelolaan limbah medis sebelumnya, dari titik ini diharapkan seni komunikasi Sales Team PPLI dapat bekerja secara maksimal. Penelitian selanjutnya dapat berfokus terhadap pengukuran akurasi strategi PPLI di pasar pengelolaan limbah media

\section{DAFTAR PUSTAKA}

Adisasmito. 2009. Sistem Manajemen Lingkungan Rumah Sakit. Jakarta: Rajawali Pers

Alvionita AP. 2018. Jurnal: Pengelolaan Limbah Padat Bahan Berbahaya Beracun (B3) Rumah Sakit di RSUD Dr.Soetomo Surabaya. Surabaya: Departemen Kesehatan Fakultas Kesehatan Masyarakt. Universitas Airlangga

Angelica T. 2016. Implementasi Analisis SWOT Dalam Strategi Pemasaran Produk Mandiri Tabungan Bisnis. Jurnal Riset Bisnis dan Manajemen 4(3). 
Pruss A et al. 2005. Pengelolaan Aman Limbah Layanan Kesehatan. Jakarta: Penerbit Buku Kedokteran EGC.

Asmadi. 2013. Pengelolaan Limbah Medis Rumah Sakit. Jakarta: Gosyen Publishing

Coman A, Ronen B. 2009. Focused SWOT: Diagnosing critical strengths and weaknesses. International Journal of Production Research 47 (20): 56775689.

Constantinides E. 2006. The Marketing Mix revisited: towards the 21 st century marketing. Journal of Marketing Management 22:407-438

David FR. 2011. Manajemen Strategi. Salemba Empat. Jakarta

Febriyanti N, Hardisman, Rima S. 2019. Jurnal: Analisis Segmentasi dan Penentuan Target Pasar Pelanggan Instalasi Rawat Jalan RS Universitas Andalas. sJurnal Kesehatan Andalan : 8 (3).

Kotler P, Amstrong G. 2008. Prinsip Prinsip Pemasaran Edisi 12. Jakarta: Erlangga

[Menkes] Menteri Kesehatan. 2011. Permenkes RI Nomor. 340/Menkes/Per/III/2010 tentang Klasifikasi Rumah Sakit. Jakarta: Departemen Kesahatan Republik Indonesia.

Munif A. 2010. Pengangkutan Sampah Medis. (http:// publichealthjournal.helpingpeopleideas.com/ pengangkutan-sampahmedis).
Nurhayati I. 2011. Pengolahan Limbah Medis Jarum RS. DR. Soetomo Dengan Incinerator Modifikasi. Jurnal Teknik WAKTU 9(01).

Pertiwi V. 2017. Jurnal: Evaluasi pengelolaan limbah Bahan Berbahaya Dan Beracun (B3) di Rumah Sakit Roemani Muhammadiyah Semarang. Jurnal kesehatan Masyarakat 5(3).

[PPLI] PT. Prasadha Pamunah Limbah Industri. 2018. Company Profile Integrated Waste Management System. Bogor: PPLi

[PPLI] PT. Prasadha Pamunah Limbah Industri. 2019. Company Broshure Medical Waste Management. Bogor: PPLi

Rano H, Syamsul M, Kirbrandoko. 2017. Bauran Pemasaran Dan Kepuasan Konsumen Agen Laku Pandai Pt. Bank XYZ. Jurnal-Aplikasi Bisnis dan Manajemen 3(3).

Sumarwan U et al. 2013. Riset Pemasaran dan Konsumen; Anova. Ancova. Regresi dan Structural Equation Modelling. serta Kajian: Posisi Produk. Ekuitas Merek. Konsep Diri. Loyalitas Toko. Sikap dan Preferensi. Strategi Harga. dan Keluhan Pelanggan. Bogor: IPB Press

[WHO] World Health Organization. 2004. Policy Paper: Safe Health Care Waste Manajement. (http://www.who.int/water_sanitation_health/ medicalwaste/en/hewmpolicye). 